Genevieve Hyacinthe, Radical Virtuosity: Ana Mendieta and the Black Atlantic.

Cambridge MA: MIT Press, 2019. xii + 333 pp. (Cloth US\$39.95)

Olga Viso's edited volume, Ana Mendieta: Earth/Body; Sculpture and Performance, 1972-1985 (2004) is widely considered a definitive analysis of this Cuban American artist's pioneering work. As Viso recognized, Mendieta's "reference to African and Afro-Cuban subjects was loose and self-styled in its appropriation" while "her invocation of such content, particularly from Santería" revealed a cursory, admittedly superficial treatment of Afro-Cuban religiosity, which Mendieta herself called "voodoo" in the early 1980s (quoted, p. 124). For Viso, critics' insistence on excavating Afro-Caribbean meanings from Mendieta's work surely contributed to her exoticization and encouraged self-mythologization, especially in traditionally Eurocentric spaces where largely White, privileged audiences engaged mostly White, privileged artists. Subsequently, José Quiroga's brilliant Cuban Palimpsests (2005) demonstrated themes far more central and intentional in Mendieta's art. Mendieta's attacks on patriarchy, Latin American masculinities, gender binaries, and Cuban exiles' authenticity narratives of identity were not only ahead of their time, but derived their visual power from troves of personal experience.

For this reason, Genevieve Hyacinthe's interpretation of Mendieta's art seems as provocative and innovative as it is paradoxical and, at times, speculative and unconvincing. Adopting "a reception-based lens," she shows how "Mendieta employs her striking performatives to institute an insurgent message of political identification and action, read here as spiritually and sociopolitically inflected black Atlantic collectivity" (p. 26). Casting aside intent and Mendieta's admittedly "surface knowledge" of the Black Atlantic movement as unnecessary, she defines Mendieta's universalizing mixology of Catholic, Afro-Cuban, and "prehistoric" indigeneity as "radical virtuosity," an effort to break boundaries, identify with the margins, and overturn White hegemony. And she offers a strong discussion of Mendieta's confrontational rebukes of the U.S. Earthworks movement, some of which involve the artist's partial entombment as a means for commenting on the exploitation and abuse of women's bodies to that of the Earth. Similarly, Hyacinthe contends, Mendieta's evocation of the Mexican indigenous female deity in Imagen de Yágul (consciously positioning "herself as artist, brush and artwork" [p. 17]) serves to "empower her audiences to join her in the struggle for political agency," not by claiming her own body as an evidentiary site for the injustice suffered by the marginalized, but rather by making her body visible only in outlined form against a backdrop provided by nature (such as a tree) or by making it literally disappear under piles of mud or dirt (p. 211). 
Nonetheless, Hyacinthe works hard to tether Mendieta to Black collectivity, often by linking her imagery to works made decades after her death or about which Mendieta knew virtually nothing. Scholars and practitioners of Regla de Ocha (Santería) may also be troubled, or mildly offended, by Hyacinthe's insistence that Mendieta unconsciously created an Afro-Cuban ritual aesthetics in her works as a "means of self-care or strategy of endurance while in exile" and "self-baptism" (p. 105).

Indeed, the facts of Mendieta's life work against Hyacinthe's case for evoking the Black Atlantic and making it "speak." As the daughter of upper-middleclass Catholic parents who vacationed in the exclusive lily-White beach town of Varadero until 1959, Mendieta derived her direct knowledge of Santería solely from observing her Black maids and servants before she left Cuba at the age of 12. In college, she took a handful of classes on "primitive art" and wrote a paper on Wifredo Lam (whose first name Hyacinthe repeatedly misspells), and as an adult she read Lydia Cabrera's El Monte. Sent with her sister to a Catholic orphanage in Iowa as part of the CIA-directed Operation Pedro Pan, Mendieta only reunited with her mother and brother five years later; Mendieta did not see her father, a political prisoner arrested for supporting the Bay of Pigs invasion, until his release in 1978. Incredibly, Mendieta courageously marked that moment by participating in a diplomatic exchange (called El Diálogo) between dozens of young, exiled intellectual peers and representatives of the Cuban government in Havana. Undoubtedly, she experienced the torments of family separation, extremes of ignorance and racism in Iowa, and the ridiculing not only of Black culture and identity but of everything deemed "nonwhite." However, one gets the feeling that Mendieta's art does not so much reflect the values, goals, or content of the Black Atlantic as it seeks to expose them and embody them as taboo. While imposing a lens on her art, Radical Virtuosity also strives to capture and explain Mendieta's visual translations of a historically shredded consciousness in ways that invite discovery, recovery, and reconstruction.

\section{Lillian Guerra}

Department of History, University of Florida, Gainesville FL, U.S.A. lillian.guerra@ufl.edu 